\title{
Antineoplastic Activity and Genotoxicity of Organic Extracts and Barbatic Acid Isolated from the Lichen Cladonia Salzmannii Nyl.
}

Joelma Pessoa Gonçalves', Mônica Cristina Barroso Martins², Maria de Lourdes Lacerda Buril ${ }^{3}$, Jaciana dos Santos Aguiar ${ }^{4}$, Teresinha Gonçalves da Silva ${ }^{4}$, Talita Giselly dos Santos Souza5, Noemia Pereira da Silva Santos ${ }^{6}$, Cristiano Aparecido Chagas ${ }^{5}$, Eugênia Cristina Pereira ${ }^{2,3}$, Emerson Peter da Silva Falcão7, Nicácio Henrique da Silva ${ }^{1,8}$

\section{Abstract}

Background: Secondary metabolites are responsible for most of the biological activities of lichens. Many of these compounds exhibit significant antineoplastic activity. The aim of the present in vitro study was to evaluate the antineoplastic and genotoxic activities of organic extracts and purified barbatic acid from the lichen Cladonia salzmannii Nyl.

Methods: The thallus of the lichen (22 g) was cleaned and dried with the solvents diethyl ether, chloroform and acetone. Organic extracts were obtained using the hot exhausted method in a Soxhlet apparatus. Barbatic acid (BAR) was purified from the ether extract $(1.3 \mathrm{~g})$. Chemical analysis of the organic extracts and purified BAR was performed using thin-layer chromatography. The purity of purified BAR was determined using high-performance liquid chromatography. The MTT method [3-(4, 5-dimethylthiazol-2-yl)-2, 5-diphenyltetrazolium bromide] and cytokinesis-block proliferation index (CBPI) were used to determine, respectively, the antioneoplastic and genotoxic activities of the organic extracts and purified BAR. The micronucleus test and comet assay were used to determine genotoxic potential of the organic extracts and purified BAR. Dimethyl sulfoxide was used as the diluting solvent of the samples in all biological tests.
1 Programa de Pós-graduação em Bioquímica e Fisiologia, UFPE, RecifePE, Brasil.

2 Programa de Pós-Graduação em Biologia Vegetal, UFPE, Recife-PE, Brasil.

3 Programa de Pós-Graduação em Geografia, UFPE, Recife-PE, Brasil.

4 Departamento de Antibióticos, UFPE, Recife-PE, Brasil.

5 Laboratório de Biodiversidade, Centro Acadêmico de Vitória, UFPE, Vitória de Santo Antão-PE, Brasil.

6 Laboratório NanoBioCel, Centro Acadêmico de Vitória, UFPE, Vitória de Santo Antão-PE, Brasil.

7 Laboratório de Síntese e Isolamento Molecular, Centro Acadêmico de Vitória, UFPE, Vitória de Santo AntãoPE, Brasil.

8 Laboratório de Produtos Naturais, Departamento de Bioquímica, UFPE, Recife-PE, Brasil.

Contact information:

Emerson Peter da Silva Falcão.

झ emerson_falco@yahoo.com.br 
Results: The $\mathrm{IC}_{50}$ results demonstrated significant antineoplastic potential of the ether extract against cell lines NCl-H292 (IC $50: 29.91 \mu \mathrm{g} /$ $\mathrm{mL})$, HEp-2 (IC $\left.{ }_{50}: 26.75 \mu \mathrm{g} / \mathrm{mL}\right)$ and HL-60 $\left(\mathrm{IC}_{50}: 3.59 \mu \mathrm{g} / \mathrm{mL}\right)$ as well as the purified BAR against cell lines HEp-2 $\left(\mathrm{IC}_{50}: 15.79 \mu \mathrm{g} / \mathrm{mL}\right)$ and MCF-7 ( $\left.\mathrm{IC}_{50}: 18.28 \mu \mathrm{g} / \mathrm{mL}\right)$. The CBPI demonstrated the cytotoxic activity of the purified BAR at all concentrations tested (5, 10, 20 and 40 $\mu \mathrm{g} / \mathrm{mL})$ and all organic extracts $(50 \mu \mathrm{g} / \mathrm{mL})$ against Ehrlich carcinoma cells. For sarcoma 180, only BAR purified at a concentration of $40 \mu \mathrm{g} /$ $\mathrm{mL}$ and the ether and chloroform extracts $(50 \mu \mathrm{g} / \mathrm{mL})$ were considered cytotoxic. The micronucleus test revealed that the purified BAR at a concentration of $5 \mu \mathrm{g} / \mathrm{mL}$ had no genotoxic potential against either tumor cell line. Furthermore, the chloroform extract and purified BAR at a concentration of $10 \mu \mathrm{g} / \mathrm{mL}$ were not considered genotoxic for sarcoma 180. In the comet assay, all compounds tested induced DNA damage in both tumor lines.

Conclusion: Based on the present results, organic extracts and purified barbatic acid from C. salzmannii exhibit antineoplastic and genotoxic activity against of the tumor cell lines tested.

\section{Keywords}

Antitumor Drugs; Depsides;

Micronuclei; Comet assay.

\section{Introduction}

Cancer is a worldwide public health problem. The World Health Organization estimates an incidence of 27 million cases and 17 million deaths in the year 2030, with an annual prevalence rate of 75 million people with cancer. The effect of this increase in cases of cancer will weigh heavily on low and middle-income countries. An estimate from 2012 demonstrated that more than $60 \%$ of all new cases occurred in developing countries, with projections of an increase to $80 \%$ of the more than 20 million new cases of cancer estimated for the year $2025[1,2]$.

The growing epidemiological relevance of neoplastic diseases has stimulated the investigation of substances that have potential treatment applications. Although radiotherapy and chemotherapy continue to be employed as treatment strategies, recovery rates rarely surpass $50 \%$ of cases, which underscores the importance of adopting therapies based on the use of cytotoxic substances [3]. The primary target of chemotherapy is to destroy tumor cells. However, most chemotherapeutic agents have nonspecific action and cause harm to both malignant and normal cells. Moreover, the resistance of tumors to drug therapies is another obstacle related to chemotherapy that compromises patient survival [4].

The discovery of medications for the treatment of cancer is related to research involving natural products, as approximately $60 \%$ of medications have a natural origin. In recent decades, diverse natural compounds have been investigated as alternatives to the high cost no adverse effects of chemotherapeutic medications [5].

Lichens have been used in folk medicine since antiquity. Most secondary lichen metabolites have 
a phenolic nature with important antimicrobial, healing, anti-inflammatory, antiseptic, anti-tumor and cytotoxic properties, making these compounds a potential source of new drugs [6]. The literature describes the anti-tumor $[7,8,9]$ and genotoxic activity of lichen substances [10, 11].

Therefore, the aim of the present study was to evaluate the cytotoxic and genotoxic activity of organic extracts and purified barbatic acid obtained from the lichen Cladonia salzmannii Nyl. against human tumor cell lines.

\section{Methods}

\section{Collection and identification of lichen material}

\section{Cladonia salzmannii Nyl. (100 g)}

was collected from an area of sandy tableland in the municipality of Alhandra in the state of Paraíba, Brazil (latitude: 70 24' 993" S; longitude: 34 57' $\left.734^{\prime \prime} \mathrm{W}\right)$. The samples were identified based on morphological and chemical characteristics. Color reactions in the cortex and medulla were performed using $10 \%$ potassium hydroxide and $40 \%$ sodium hypochlorite ( $\mathrm{K}$ test and $\mathrm{C}$ test, respectively). Identification keys were also used. A voucher was deposited at the Geraldo Mariz Herbarium of the Botany Department of the Universidade Federal de Pernambuco, Brazil (voucher $n^{\circ}$ 47.998).

\section{Obtainment of organic extracts and isolation and purification of barbatic acid (BAR)}

The organic extracts were obtained from $22 \mathrm{~g}$ of clean, dried lichen material with the solvents diethyl ether, chloroform and acetone, using the hot exhausted method in a Soxhlet apparatus in a hot bath at the ebullition temperature of each solvent for $12 \mathrm{~h}$ with $150 \mathrm{~mL}$ of each solvent obeying an eluotropic series. The ether (E), chloroform (C) and acetone $(A)$ organic extracts were evaporated in a rotary evaporator coupled to a hot bath at a temperature of $40^{\circ} \mathrm{C}$ and placed in a desiccator for the subsequent calculation of the yields. The previously dried ether extract (1.3 g) was submitted to successive washing in a $\mathrm{G} 4$ porous bottom funnel with 1 $\mathrm{mL}$ de chloroform (4x), as described by Asahina and Shibata [12], to obtain purified BAR.

\section{Chemical analysis of organic extracts and purified BAR}

\section{Thin-layer chromatography (TLC)}

The organic extract and the purity of the purified BAR were evaluated qualitatively using one-dimensional ascendant TLC. The organic extracts, BAR purified from C. salzmannii and standard BAR obtained from the Natural Product Laboratory of the Universidade Federal de Pernambuco (UFPE) were dissolved in $50 \mu \mathrm{L}$ of diethyl ether, applied (1 $\mu \mathrm{L}$ ) to plates of Merck ${ }^{\circledR}$ silica gel $60 \mathrm{~F}_{254+366}$ and developed in the A solvent system (toluene/dioxane/ acetic acid [45:12.5:2, v/v/v]). The chromatogram bands were viewed under UV light with short and long wavelengths (254 nm and $366 \mathrm{~nm}$ ) and subsequently developed through vaporization with $10 \%$ sulfuric acid and heating at $50^{\circ} \mathrm{C}$ for 10 minutes on a hot plate. The results were evaluated based on the color reaction of the bands and the calculation of respective retention factors (Rf) in comparison to the barbatic acid standard [13].

\section{High-performance liquid chromatography (HPLC)}

The HPLC analysis of the organic extracts and purified BAR was performed in a HITACHI chromatograph (model 655A-11) coupled to a CG UV detector (model CG437-B). The chromatography conditions followed the method described by Legaz and Vicente [14]: MicroPack $\mathrm{MCH}-18$ reverse phase column $(250 \times 4.6 \mathrm{~mm})$ with an injection volume of 20 $\mu \mathrm{L}$; isocratic mobile phase comprised of methanol, water and acetic acid (80:19.5:0.5 v/v/v); pressure 88 atm; room temperature $\left(28^{\circ} \mathrm{C} \pm 3^{\circ} \mathrm{C}\right)$; UV detector set to $254 \mathrm{~nm}$ in internal standards of $0.1 \mathrm{mg} \cdot \mathrm{mL}^{-1}$. 
The purified BAR was diluted in diethyl ether until reaching a concentration of $0.1 \mathrm{mg} \cdot \mathrm{mL}^{-1}$ and injected into the device. The results were analyzed through a comparison of the retention times of the purified and standard BAR.

\section{Infrared (IR)}

Proton nuclear magnetic resonance (NMR ${ }^{1} \mathrm{H}$ ) and carbon 13 nuclear magnetic resonance (NMR ${ }^{13} \mathrm{C}$ ): IR analysis was performed in a spectrophotometer with a Bruker Fourier transformer (model IF 566) using $\mathrm{KBr}$ pellets. The NMR ${ }^{1} \mathrm{H}$ and NMR ${ }^{13} \mathrm{C}$ spectra of the purified BAR were recorded in a Varian Unity Plus $300 \mathrm{MHz}$ spectrometer. NMR ${ }^{13} \mathrm{C}$ was operated at $75 \mathrm{MHz}$ and $\mathrm{NMR}{ }^{1} \mathrm{H}$ was operated at $300 \mathrm{MHz}$, using DMSO-d6 as the solvent in 5-mm tubes at room temperature.

\section{In vitro antineoplastic assays}

The following cells were used for the evaluation of cytotoxic activity: RAW 264.7 (murine macrophages), NCl-H292 (human lung mucoepidermoid carcinoma), HEp-2 (human larynx carcinoma), MCF-7 (human breast adenocarcinoma) and HL-60 (acute promyelocytic leukemia). All cell lines were obtained from the Cell Culture Laboratory of the Department of Antibiotics of UFPE, Brazil. The RAW 264.7, NClH292 and HEp-2 cells were maintained in Dulbecco's Modified Eagle Medium (DMEM) (SIGMA). The MCF-7 and HL-60 tumor cells were kept in the RPMI 1640 culture medium created by the Roswell Park Memorial Institute. The media were supplemented with 10\% fetal bovine serum (GIBCO) and a 1\% antibiotic solution (penicillin and streptomycin). The cells were kept at $37^{\circ} \mathrm{C}$ in a humid atmosphere enriched with $5 \% \mathrm{CO}_{2}$.

The organic extracts and purified BAR were submitted to cytotoxicity assays using the MTT colorimetric method [3-(4, 5-dimethylthiazol-2-yl)-2, 5-diphenyltetrazolium bromide] [15, 16]. THE RAW 264.7, NCl-H292, MCF-7, HEp-2 (10 5 cells/mL) and $\mathrm{HL}-60\left(0.3 \times 10^{6}\right.$ cells $\left./ \mathrm{mL}\right)$ cells were plated $(190 \mu \mathrm{L})$ in 96-well plates and incubated for $24 \mathrm{~h}$. Next, 10 $\mu \mathrm{L}$ of the samples dissolved in DMSO (0.5\%) (organic extracts: $10 \mathrm{mg} / \mathrm{mL}$; purified BAR: $5 \mathrm{mg} / \mathrm{mL}$ ) were added to the wells at concentrations of 50,25 , $12.5,6.25$ and $3.12 \mu \mathrm{g} / \mathrm{mL}$ for the organic extracts and concentrations of $25,12.5,6.25,3.12$ and 1.56 $\mu \mathrm{g} / \mathrm{mL}$ for the purified BAR. The drug doxorubicin at a concentration of $5 \mu \mathrm{g} / \mathrm{mL}$ was used as the positive control and DMSO (0.5\%) was used as the negative control. After $72 \mathrm{~h}$ of incubation, $25 \mu \mathrm{L}$ of MTT (5 $\mathrm{mg} / \mathrm{mL}$ ) were added and the plates were incubated again for $3 \mathrm{~h}$, after which the culture medium with the MTT was aspirated and $100 \mu \mathrm{L}$ of DMSO were added to each well to solubilize the crystals that had formed.

Absorbance was read in a microplate reader at a wavelength of $560 \mathrm{~nm}$. The experiments were conducted in quadruplicate. An intensity scale was used to evaluate the cytotoxic potential of the samples based on the percentage of growth inhibition: $95-100 \%=$ high potential; $70-90 \%=$ moderate potential; $<50 \%=$ no potential [17]. The concentration that inhibits growth by $50 \%$ in comparison to the negative control $\left(\mathrm{IC}_{50}\right)$ was determined considering moderate inhibitory activity (70\%) or higher.

\section{In vitro genotoxicity assays: micronucleus test and comet assay}

Sarcoma 180 and Ehrlich carcinoma cells maintained in mice in their ascitic forms were used for the genotoxicity assays. The cells were obtained during the weekly maintenance of the tumors. The tumor lines were maintained through the intraperitoneal transference of the ascitic fluid of the donor animal to the receptor mouse. As only a suspension of 0.6 $\mathrm{mL}$ of aspirated ascitic fluid and $0.4 \mathrm{~mL}$ of $0.9 \%$ saline solution was inoculated into the receptor mouse, the remaining aspirated ascitic fluid was used for the in vitro tests. At the Nanotechnology, Biotechnology and Cell Culture Laboratory of the Academic Center of Vitória of UFPE, Brazil, the ascitic tumors sarcoma 180 and Ehrlich carcinoma 
were transferred to Falcon tubes and centrifuged for $5 \mathrm{~min}$ at $2500 \mathrm{rpm}$. The supernatant was discarded and a 100- $\mu \mathrm{L}$ sample of the cell precipitate was re-suspended in $900 \mu \mathrm{L}$ of DMEM culture medium (SIGMA) for the cell count in a Neubauer chamber. Based on the count, the concentration of cells was adjusted with the culture medium to $10^{6}$ cells $/ \mathrm{mL}$.

For the micronucleus test, the tumor cells $\left(10^{6}\right.$ cells $/ \mathrm{mL})$ were plated $(900 \mu \mathrm{L})$ in 24 -well plates. The samples dissolved in DMSO (0.5\%) were added to the wells $(100 \mu \mathrm{L})$ at a final concentration of 50 $\mu \mathrm{g} / \mathrm{mL}$ for the organic extracts and 20 and $40 \mu \mathrm{g} /$ $\mathrm{mL}$ for the purified BAR. The drugs cyclophosphamide and colchicine $(50 \mu \mathrm{g} / \mathrm{mL})$ were used as the positive controls and DMSO $(0.5 \%)$ was used as the negative control. Next, slides were prepared for the microscopic analysis. For such, the cells were stained with acridine orange $0.04 \mathrm{M}$.

The slides were analyzed in a blind test under a fluorescence microscope (Axio Imager.M2, Zeiss) with magnification of $1000 \mathrm{x}$ and using an Alexa Fluor 488 filter. The analysis of micronuclei and bi-nucleated cells was based on Fenech [18]. The experiment was conducted in triplicate. Therefore, 3000 cells (1000 cells/slide) were evaluated for each treatment. The cytokinesis-block proliferation index (CBPI) was determined by the number o mononucleated, binucleated and multinucleated cells found among 1500 cells analyzed per treatment (500 cells/ slide). The CBPI was calculated based on the OECD Guidelines for Testing of Chemicals [19], using the following formula:

$$
\begin{gathered}
\text { CBPI }=\left[\left(\mathrm{N}^{\circ} \text { of mononucleated cells }\right)+\left(2 \times \mathrm{N}^{\circ}\right.\right. \\
\text { of binucleated cells })+ \\
\left.\left.3 \times \mathrm{N}^{\circ} \text { of multinucleated cells }\right)\right] \\
\text { (total number of cells })
\end{gathered}
$$

For the comet test, the tumor cells $\left(10^{6}\right.$ cells $\left./ \mathrm{mL}\right)$ were plated and treated under the same condi-

tions as those described for the micronucleus test. Cells in treated culture for $6 \mathrm{~h}$ with the samples were removed from the plate, centrifuged and resuspended in new DMEM. The comet assay was performed based on Speit and Hartmann [20]. The stain was ethydium bromide and the analysis was performed using a fluorescence microscope (Axio Imager.M2, Zeiss) with magnification of $400 x$ and using an Alexa Fluor 546 filter. A total of 300 cells were analyzed per treatment (100 cells/slide).

The extent of the DNA that migrated from the nucleus was analyzed based on the visual classification described by Collins et al. [21]. From the classification of the cells analyzed, the results were evaluated according to two parameters: the damage index (DI: 0-400) and damage frequency (DF: 0-100\%). The $\mathrm{DI}$ is the result of the sum of the number of cells found in each class multiplied by the value of the respective class. The DF is obtained from the total number of cells analyzed subtracted from the number of cells classified as grade 0 , resulting in a percentage value of cells that exhibit any degree of detectable damage (1-4).

\section{Statistical analysis}

The percentage of inhibition $\left(\mathrm{IC}_{50}\right)$ and respective 95\% confidence intervals $(\mathrm{Cl})$ obtained from the nonlinear regression were calculated with the aid of the GraphPad Prism 5.0 program. The level of significance was set to $5 \%$. Fisher's exact test was used to determine differences in the frequencies of micronuclei between each treated group and the negative control as well as the group that received only DMSO. The Kruskal-Wallis with a posteriori analysis was used for the hypothesis tests referring to the CBPI, DI and DF, using the pairwise t-test strategy with the Bonferroni correction. For all hypothesis tests, the level of significance was set to $5 \%$. All analyses were performed in the R software [22]. 


\section{Results}

\section{Obtainment of organic extracts and chemical analysis of samples}

The yield of the organic extract demonstrated the efficiency of diethyl ether in the hot exhausted extraction process, as the yield was higher (7.65\%) in comparison to that achieved with chloroform $(0.04 \%)$ and acetone $(0.03 \%)$. The TLC analysis revealed the presence of BAR in all organic extracts (Rf: 0.57) (Figure 1). Two other bands were evidenced in the acetone extract (Rf: 0.15 and 0.18), corresponding to other compounds that may be present in C. salzmannii, such as the thamnolic acid and Dthamnolic acid described by AHTI, STENROOS and XAVIER-FILHO [23] (1993). Point 4, which corresponds to the purified BAR, had one band, which was compatible with the $\mathrm{Rf}$ of the BAR standard (0.57).

Figure 1: Schematic model of thin-layer chromatogram of organic extracts from $C$. salzmannii Nyl. and BAR purified from ether extract.

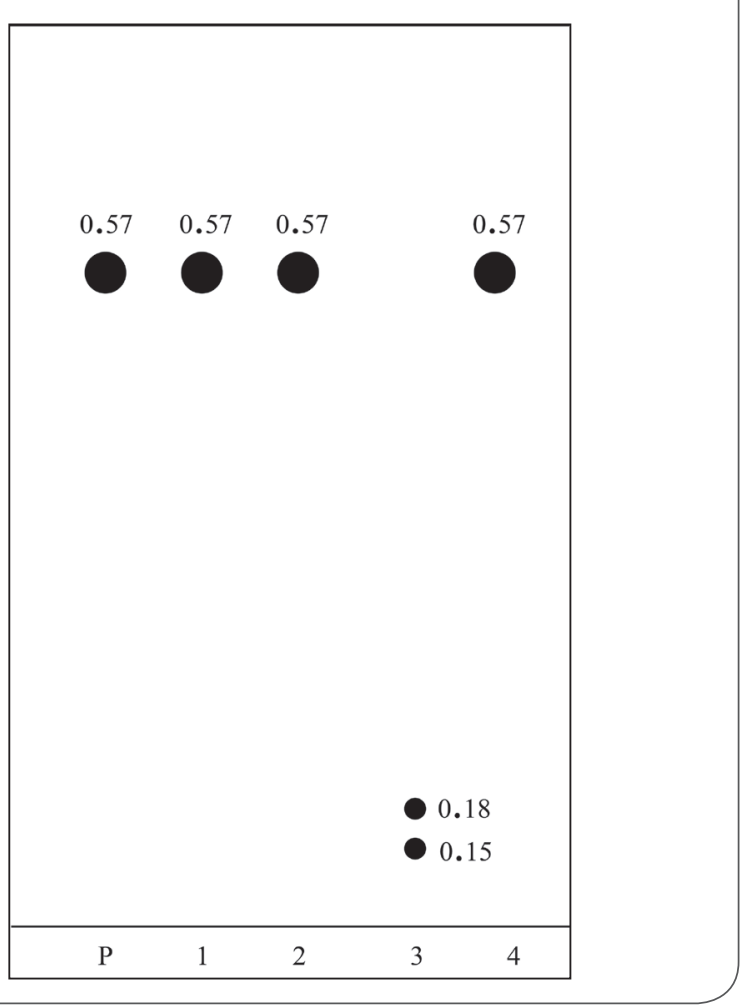

The organic extract, purified BAR and standard BAR were submitted to HPLC. A peak corresponding to the purified BAR (Tr: $19.09 \mathrm{~min}$ ) demonstrated $96.3 \%$ purity (Figure 2 ). The HPLC analysis (Figure 2A-D) demonstrated the presence of barbatic acid in the chloroform and ether extracts (Figure 2A \& D), with the higher level of this phenol found

Figure 2: HPLC chromatogram of purified BAR
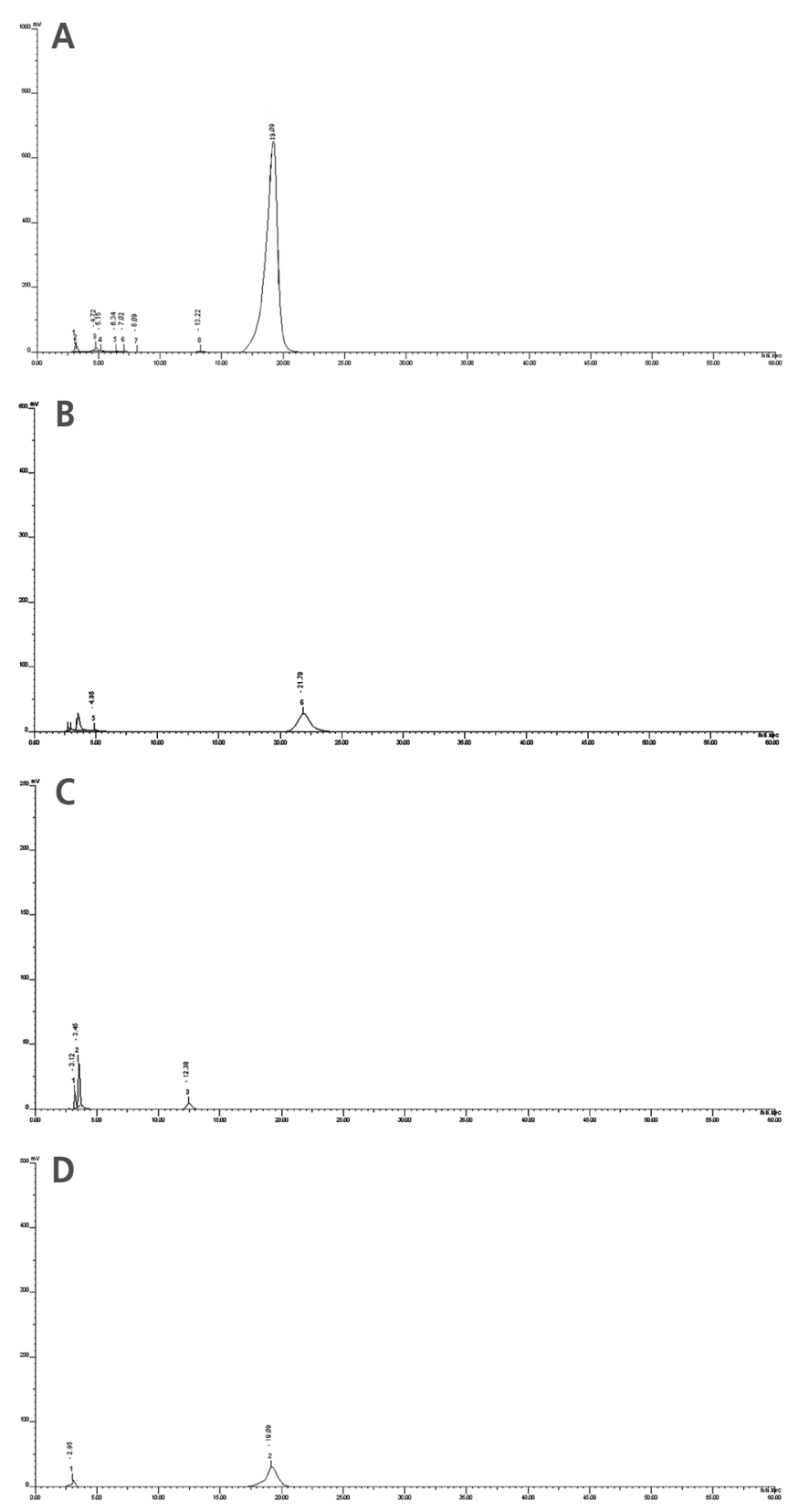

A) diethyl ether (Tr: 4.15 min); B) purified BAR (Tr: 19.09min); C) Acetone extract; D) Chloroform extract. 
in the ether extract. This component was not found in the acetone extract (Figure $\mathbf{2 C}$ ), for which two peaks were found ( $\operatorname{Tr} 3.45$ and $12.38 \mathrm{~min}$ ).

The infrared, NMR ${ }^{1} \mathrm{H}$ and NMR ${ }^{13} \mathrm{C}$ analyses confirmed the chemical structure of the purified BAR. The following data describe the results of these analyses: IR ( $\mathrm{KBr}$ ) cm $\mathrm{cm}^{-1}$ : 3100 (v C-H) aromatic; 2984 $\left(\mathrm{v}_{\text {as }} \mathrm{CH}_{3}\right) ; 2932\left(\mathrm{v}_{\mathrm{s}} \mathrm{CH}_{3}\right) ; 1720$ ( $\left.\mathrm{v} \mathrm{O}=\mathrm{C}-\mathrm{O}\right)$ ester; 1660 ( $v$ Ar- $\mathrm{O}=\mathrm{C}-\mathrm{O}$ ) ester conjugated with aromatic ring; 1574 and 1505 ( $v \mathrm{C}=\mathrm{C}$ ) aromatic; $1444\left(\mathrm{v}_{\text {as }} \mathrm{CH}_{3}\right)$; $1390\left(\mathrm{v}_{\mathrm{s}} \mathrm{CH}_{3}\right) ; 1233$ and 1130 ( $\mathrm{v}$ two bands confirming ester). NMR ${ }^{1} \mathrm{H}\left(299 \mathrm{MHz}, \mathrm{DMSO}-\mathrm{d}_{6}\right) \delta \mathrm{H}$ : $1.99\left(3 \mathrm{H} ; s, \mathrm{Me}-8^{\prime}\right): 2.00$ (3H; s, Me-8); 2.41 (3H; s, Me-9'); $2.56(3 \mathrm{H} ; s, \mathrm{Me}-9) ; 3.86(3 \mathrm{H} ; s, \mathrm{MeO}-$ 4), $6.60(1 \mathrm{H} ; \mathrm{s}, \mathrm{H}-5) ; 6.69\left(1 \mathrm{H} ; \mathrm{s}, \mathrm{H}-5^{\prime}\right), 10.73(1 \mathrm{H}$; s, HO-2). NMR ${ }^{13} \mathrm{C}(75 \mathrm{MHz}$, DMSO-d6) $\delta \mathrm{C}: \mathrm{C}-1$ : 110.0; C-2: 151.8; C-3: 106.3; C-4: 161.3; C-5: 107.1; C-6: 138.9; C-7: 168.6; C-8: 8.1; C-9: 22.8; C-4-OMe: 55.7; C-1': 159.4; C-2': 111.4; C-3': 161.1; C-4': 116.1; C-5': 139.0; C-6': 116.1; C-7': 173.2; C-8': 9.1; C-9': 23.8.

\section{Cytotoxic activity of organic extract and purified BAR}

Table 1 displays the inhibitory capacity of the organic extracts, purified BAR and doxorubicin (positive control) regarding the growth of the tumor cells. The ether extract demonstrated moderate inhibitory capacity (cell growth inhibition ranging from 70 to 90\%) toward the RAW-264.7, NCl-H292, HEP-2 and HL-60 cell lines, but exhibited no cytotoxic poten- tial with regard to MCF-7. The chloroform extract demonstrated moderate inhibitory capacity toward HEP-2 and MCF-7, but had no significant inhibitory effect on RAW-264.7, NCl-H292 or HL-60. The acetone extract demonstrated high inhibitory capacity (95-100\%) toward $\mathrm{NCl}-\mathrm{H} 292$ and moderate inhibitory capacity toward MCF-7, but had no significant effect on the growth of RAW-264.7, HEP-2 or HL-60. The purified BAR demonstrated moderate inhibitory capacity toward RAW-264.7, HEP-2 and MCF-7, but had no significant effect on NCl-H292 or HL-60.

The purified BAR and organic extracts that exhibited moderate to high inhibitory activity were tested at different concentrations $(0.098$ to $25 \mu \mathrm{g} /$ $\mathrm{mL}$ for purified BAR and 0.098 to $50 \mu \mathrm{g} / \mathrm{mL}$ for organic extracts) for the determination of $\mathrm{IC}_{50}$ values. Doxorubicin (0.009 to $1.25 \mu \mathrm{g} / \mathrm{mL}$ ) was used as the standard.

Table 2 displays the $I C_{50}$ values of the organic extract and purified BAR. The purified BAR exhibited cytotoxic potential against all cell lines tested. The ether extract exhibited cytotoxic potential against the neoplastic cell lines testes, particularly $\mathrm{HL}-60\left(\mathrm{IC}_{50}=3.59 \mu \mathrm{g} / \mathrm{mL}\right)$, but did not exhibit cytotoxic potential against RAW-264.7 $\left(\mathrm{IC}_{50}=36.54\right.$ $\mu \mathrm{g} / \mathrm{mL})$. The chloroform extract exhibited no significant cytotoxic potential against the cell lines. The acetone extract exhibited cytotoxic potential against $\mathrm{NCl}-\mathrm{H} 292$ and MCF-7.

Table 1. Percentage of inhibition to growth of human tumor cell lines and macrophage.

\begin{tabular}{|c|c|c|c|c|c|c|}
\hline \multirow{2}{*}{ Samples } & \multirow{2}{*}{$\begin{array}{c}\text { Concentration } \\
(\mu \mathrm{g} / \mathrm{mL})\end{array}$} & \multicolumn{5}{|c|}{$\%$ of inhibition } \\
\hline & & RAW-264.7 & $\mathrm{NCl}-\mathrm{H} 292$ & HEP-2 & $\mathrm{HL}-60$ & MCF-7 \\
\hline Doxorubicin & 1.25 & $96.5 \pm 0.8$ & $94.1 \pm 2.0$ & $79.4 \pm 2.6$ & $92.9 \pm 0.6$ & $74.8 \pm 2.1$ \\
\hline Purified BAR & 25 & $79.2 \pm 1.9$ & $8.7 \pm 0.4$ & $86.5 \pm 3.9$ & $41.4 \pm 3.1$ & $71.1 \pm 4.4$ \\
\hline E extract & 50 & $82.5 \pm 1.1$ & $80.1 \pm 5.0$ & $89.5 \pm 4.2$ & $83.9 \pm 4.4$ & $50.9 \pm 2.3$ \\
\hline C extract & 50 & $23.3 \pm 0.0$ & $58.7 \pm 2.1$ & $73.4 \pm 3.6$ & $58.0 \pm 3.1$ & $72.0 \pm 1.3$ \\
\hline A extract & 50 & $59.6 \pm 1.2$ & $98.4 \pm 0.9$ & $62.6 \pm 1.3$ & $38.0 \pm 1.6$ & $71.3 \pm 1.0$ \\
\hline
\end{tabular}


Table 2. $\mathrm{Cl}_{50}$ of purified BAR and organic extracts .

\begin{tabular}{|c|c|c|c|c|c|c|}
\hline \multirow{2}{*}{ Samples } & \multirow{2}{*}{$\begin{array}{c}\text { Concentration } \\
(\mu \mathrm{g} / \mathrm{mL})\end{array}$} & \multicolumn{5}{|c|}{$\%$ of inhibition } \\
\hline & & RAW-264.7 & $\mathrm{NCl}-\mathrm{H} 292$ & HEP-2 & HL-60 & MCF-7 \\
\hline \multirow{2}{*}{ Doxorubicin } & \multirow{2}{*}{1.25} & 0.35 & 0.08 & 0.31 & 0.06 & 0.11 \\
\hline & & $0.26-0.47$ & $0.06-0.12$ & $0.26-0.36$ & $0.05-0.07$ & $0.08-0.15$ \\
\hline \multirow{2}{*}{ Purified BAR } & \multirow{2}{*}{25} & 20.79 & \multirow{2}{*}{ NT } & 15.79 & \multirow{2}{*}{ NT } & 18.28 \\
\hline & & $18.54-23.32$ & & $13.59-18.34$ & & $13.05-25.62$ \\
\hline \multirow{2}{*}{ E extract } & \multirow{2}{*}{50} & 36.54 & 29.91 & 26.75 & 3.59 & \multirow{2}{*}{ NT } \\
\hline & & $33.85-40.26$ & $26.20-34.14$ & $22.13-32.35$ & $2.38-5.41$ & \\
\hline \multirow{2}{*}{ C extract } & \multirow{2}{*}{50} & \multirow{2}{*}{ NT } & \multirow{2}{*}{ NT } & 33.80 & \multirow{2}{*}{ NT } & 36.5 \\
\hline & & & & $28.0-41.0$ & & $29.51-45.13$ \\
\hline \multirow{2}{*}{ A extract } & \multirow{2}{*}{50} & \multirow{2}{*}{ NT } & 16.60 & \multirow{2}{*}{ NT } & \multirow{2}{*}{ NT } & 7.55 \\
\hline & & & $14.21-19.40$ & & & $6.02-9.48$ \\
\hline
\end{tabular}

\section{Genotoxic activity of organic extract and purified BAR}

Table 3 displays the mean CBPI of the sarcoma 180 and Ehrlich carcinoma tumor lines. All samples tested had significantly different CBPI values from that of the negative control for Ehrlich carcinoma. For

Table 3. Mean cytokinesis-block proliferation index (CBPI) of cell lines treated with purified BAR and organic extracts $(\mu \mathrm{g} / \mathrm{mL})$ obtained from C. salzmannii Nyl.

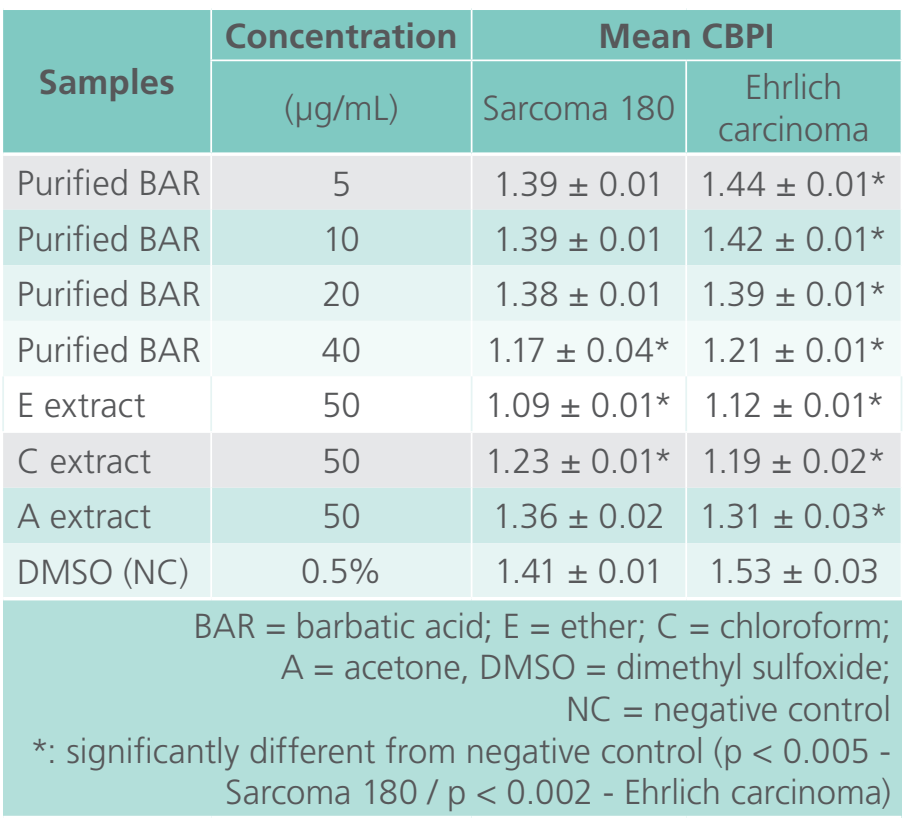

sarcoma 180, however, only the purified BAR at a concentration of $40 \mu \mathrm{g} / \mathrm{mL}$ and the ether and chloroform extracts at a concentration of $50 \mu \mathrm{g} /$ $\mathrm{mL}$ had significantly different CBPI values from that of the negative control. Therefore, considering cell proliferation, Ehrlich carcinoma demonstrated high sensitivity to all samples tested.

Table 4 displays the mean number of micronuclei (MN) per treatment in the sarcoma 180 and Ehrlich carcinoma cell lines. For sarcoma 180, statistically significant differences were found for all treatments in comparison to the negative control (DMSO), with the exception of the chloroform extract at a concentration of $50 \mu \mathrm{g} / \mathrm{mL}$ and the purified BAR at concentrations of 5 and $10 \mu \mathrm{g} / \mathrm{mL}$. For Ehrlich carcinoma, all treatments differed significantly from the negative control except the purified BAR at a concentration of $5 \mu \mathrm{g} / \mathrm{mL}$.

According to the comet assay, all samples induced damage to DNA in both the sarcoma 180 and Ehrlich carcinoma tumor lines (Table $5 \&$ 6). Considering the damage frequency and damage index, the purified BAR at a concentration of $40 \mu \mathrm{g} / \mathrm{mL}$ exhibited the greatest damage to the DNA in both tumor lines. 
Table 4. Mean frequency of micronuclei (MN) in binucleated cells treated with purified BAR and organic extracts $(\mu \mathrm{g} / \mathrm{mL})$ obtained from C. salzmannii Nyl.

\begin{tabular}{|c|c|c|c|}
\hline \multirow[b]{2}{*}{ Samples } & \multirow{2}{*}{$\begin{array}{c}\text { Concentration } \\
(\mu \mathrm{g} / \mathrm{mL})\end{array}$} & \multicolumn{2}{|c|}{ Mean frequency of MN } \\
\hline & & $\begin{array}{c}\text { Sarcoma } \\
180\end{array}$ & $\begin{array}{c}\text { Ehrlich } \\
\text { carcinoma }\end{array}$ \\
\hline Purified BAR & 5 & $16.3 \pm 4.04$ & $9.7 \pm 1.53$ \\
\hline Purified BAR & 10 & $18 \pm 3.00$ & $15.3 \pm 3.51^{*}$ \\
\hline Purified BAR & 20 & $32 \pm 5.09 *$ & $19.7 \pm 2.64^{*}$ \\
\hline Purified BAR & 40 & $35 \pm 6.37^{\star}$ & $21.3 \pm 3.23^{*}$ \\
\hline E extract & 50 & $39.3 \pm 6.21 *$ & $30.7 \pm 3.42 *$ \\
\hline C extract & 50 & $18.3 \pm 4.46$ & $14.3 \pm 4.41^{\star}$ \\
\hline A extract & 50 & $24.7 \pm 6.18^{*}$ & $20.3 \pm 4.59 *$ \\
\hline $\begin{array}{l}\text { Cyclo- } \\
\text { phosphamide } \\
\text { (PC) }\end{array}$ & 50 & $54.7 \pm 2.84^{*}$ & $35 \pm 4.24^{\star}$ \\
\hline $\begin{array}{l}\text { Colchicine } \\
\text { (PC) }\end{array}$ & 50 & $69 \pm 2.93^{*}$ & $45.7 \pm 3.38 *$ \\
\hline DMSO (NC) & $0.5 \%$ & $9.3 \pm 3.39$ & $3.0 \pm 1.61$ \\
\hline \multicolumn{4}{|c|}{$\begin{array}{r}\mathrm{MN}=\text { micronuclei; } \mathrm{BAR}=\text { barbatic acid; } \mathrm{E}=\text { ether; } \\
\mathrm{C} \text { = chloroform; } \mathrm{A}=\text { acetone; } \mathrm{DMSO}=\text { dimethyl sulfoxide; } \\
\mathrm{PC}=\text { positive control; } \mathrm{NC}=\text { negative control } \\
\text { *: significantly different from negative control }(\mathrm{p}<0.005 \\
\text { - Sarcoma } 180 / \mathrm{p}<0.002 \text { - Ehrlich carcinoma) }\end{array}$} \\
\hline
\end{tabular}

Table 5. Mean damage frequency for cell lines treated with purified BAR and organic extracts $(\mu \mathrm{g} / \mathrm{mL})$ obtained from C. salzmannii Nyl.

\section{Concentration Mean damage frequency}

\begin{tabular}{|c|c|c|c|}
\hline \multirow[b]{2}{*}{ Samples } & \multicolumn{3}{|r|}{ e I } \\
\hline & $(\mu \mathrm{g} / \mathrm{mL})$ & $\begin{array}{c}\text { Sarcoma } \\
180\end{array}$ & $\begin{array}{c}\text { Ehrlich } \\
\text { carcinoma }\end{array}$ \\
\hline
\end{tabular}

$\begin{array}{lll}\text { Purified BAR } & 5 & 41.3 \pm 2.51 \text { * } 67.6 \pm 4.51 \text { * }\end{array}$

\begin{tabular}{ll|l} 
Purified BAR & 10 & $71.7 \pm 2.31 * 68.6 \pm 3.21$ *
\end{tabular}

$\begin{array}{lll}\text { Purified BAR } & 20 & 86.7 \pm 1.41 * 78.6 \pm 2.51 *\end{array}$

Purified BAR $40 \quad 92.3 \pm 1.26 * 91 \pm 2.00$ *

\begin{tabular}{l|ll} 
E extract & 50 & $93.3 \pm 0.54 * 87.3 \pm 1.52 *$
\end{tabular}

C extract $\quad 50 \quad 79.3 \pm 1.73 * 80.6 \pm 2.51$ *

A extract $\quad 50 \quad 45.7 \pm 1.41$ * $38.6 \pm 2.51$ *

Cyclo-

phosphamide $\quad 50 \quad 100 \pm 0.00$ * $98.6 \pm 1.15^{*}$

(PC)

Colchicine

$\begin{array}{lll}(P C) & 50 & 99.7 \pm 0.54 * 99.6 \pm 0.57 *\end{array}$

DMSO (NC)

$0.5 \%$

$17.0 \pm 1.63 \quad 11.3 \pm 2.08$

$B A R=$ barbatic acid; $E$ = ether $; C=$ chloroform; $\mathrm{A}=$ acetone; $\mathrm{DMSO}=$ dimethyl sulfoxide; $\mathrm{PC}=$ positive control; NC = negative control; *: statistically significant difference compared to negative control ( $p<0.002)$.
Table 6. Mean damage index for cell lines treated with purified BAR and organic extracts $(\mu \mathrm{g} / \mathrm{mL})$ obtained from C. salzmannii Nyl.

\begin{tabular}{|c|c|c|c|}
\hline \multirow[b]{2}{*}{ Samples } & \multirow{2}{*}{$\begin{array}{c}\text { Concentration } \\
(\mu \mathrm{g} / \mathrm{mL})\end{array}$} & \multicolumn{2}{|c|}{ Mean damage frequency } \\
\hline & & $\begin{array}{c}\text { Sarcoma } \\
180\end{array}$ & $\begin{array}{c}\text { Ehrlich } \\
\text { carcinoma }\end{array}$ \\
\hline Purified BAR & 5 & $82.7 \pm 8.14^{*}$ & $149.3 \pm 5.77 *$ \\
\hline Purified BAR & 10 & $165.7 \pm 5.50 *$ & $150.6 \pm 11.92^{*}$ \\
\hline Purified BAR & 20 & $237.7 \pm 6.50^{*}$ & $172.3 \pm 3.78^{*}$ \\
\hline Purified BAR & 40 & $255 \pm 7.81^{*}$ & $254.6 \pm 12.50 *$ \\
\hline E extract & 50 & $244.7 \pm 8.38^{*}$ & $233.6 \pm 3.51^{*}$ \\
\hline C extract & 50 & $169.7 \pm 11.80$ * & $181.3 \pm 5.85^{\star}$ \\
\hline A extract & 50 & $71.7 \pm 4.50^{*}$ & $63.6 \pm 5.50^{*}$ \\
\hline $\begin{array}{l}\text { Cyclo- } \\
\text { phosphamide } \\
\text { (PC) }\end{array}$ & 50 & $308.7 \pm 6.65^{\star}$ & $278 \pm 2.00 *$ \\
\hline $\begin{array}{l}\text { Colchicine } \\
\text { (PC) }\end{array}$ & 50 & $329.3 \pm 7.57^{*}$ & $314 \pm 4.00 *$ \\
\hline DMSO (NC) & $0.5 \%$ & $19 \pm 2.64$ & $12 \pm 2.64$ \\
\hline \multicolumn{4}{|c|}{$\begin{array}{r}\mathrm{BAR}=\text { barbatic acid; } \mathrm{E}=\text { ether } ; \mathrm{C}=\text { chloroform; } \mathrm{A}=\text { acetone; } \\
\mathrm{DMSO}=\text { dimethyl sulfoxide; } \mathrm{PC}=\text { positive control; } \\
\mathrm{NC}=\text { negative control; }{ }^{*} \text { : statistically significant difference } \\
\text { compared to negative control }(\mathrm{p}<0.002)\end{array}$} \\
\hline
\end{tabular}




\section{Discussion}

The chromatographic analyses (TLC and HPLC) revealed the presence of barbatic acid in the ether and chloroform extracts obtained from C. salzmannii. This is the main compound found in the species, as described by AHTI, STENROOS and XAVIERFILHO [23]. According to the authors, 4-O-dimethyl barbatic, thamnolic and D-thamnolic acids are also occasionally found in the species. The chromatographic analyses also demonstrated additional bands and peaks consistent with the presence of thamnolic and D-thamnolic acids.

Based on the $I C_{50}$ values, considerable antineoplastic potential was found for the ether and acetone extracts and the purified BAR against the tumor cells investigated. According to the US National Cancer, extracts with an $\mathrm{IC}_{50} \leq 4 \mu \mathrm{g} / \mathrm{mL}$ are considered promising drugs for cancer treatment [24]. Therefore, the ether extract demonstrated high antineoplastic activity against the HL-60 cell line $\left(I_{50}=3.59 \mu \mathrm{g} / \mathrm{mL}\right)$. Considering the cytokinesis-block proliferation index (CBPI), the cytotoxic activity of the purified BAR at concentrations of 5, 10, 20 and $40 \mu \mathrm{g} / \mathrm{mL}$ and the activity of the organic extracts at a concentration of $50 \mu \mathrm{g} / \mathrm{mL}$ was relevant, specifically toward Ehrlich carcinoma cells. However, only the purified BAR at a concentration of $40 \mu \mathrm{g} / \mathrm{mL}$ and the chloroform and ether extracts at a concentration of $50 \mu \mathrm{g} / \mathrm{mL}$ were considered cytotoxic to sarcoma 180. This tumor is considered more resistant to chemotherapeutic drugs. Therefore, the findings show that Erhlich carcinoma demonstrated high sensitivity to the samples tested.

In a previous study, Martins et al. [25] demonstrated the antineoplastic potential of the ether extract and purified barbatic acid from $C$. aggregata against the HEp-2, NCl-H292 and KB cell lines. The results demonstrated greater antineoplastic potential for the ether extract and the authors suggest that this effect is due to the synergic action of the components of the extract. Moreover, dose-dependent antineoplastic activity was found for all samples. In the present study, no synergic effect was found on the cells lines tested.

In a study that has not yet been published, Tavares [26] evaluated the cytotoxicity of encapsulated BAR purified from C. salzmannii against the J774, sarcoma 180 and Ehrlich carcinoma cells lines. The results also demonstrate the dose-dependent cytotoxic potential of purified BAR.

The results of the comet assay demonstrated the genotoxic effect on sarcoma 180 and Ehrlich carcinoma of all samples tested. However, the micronucleus test demonstrated that the purified BAR at a concentration of $5 \mu \mathrm{g} / \mathrm{mL}$ was not genotoxic to either cell line. Moreover, the micronucleus test demonstrated that that the chloroform extract and purified BAR at a concentration of $10 \mu \mathrm{g} / \mathrm{mL}$ were not genotoxic to sarcoma 180. In the literature, previous studies have evaluated the genotoxicity of substances stemming from the secondary metabolism of lichens. The in vitro and in vivo genotoxicity of usnic acid obtained from Usnea steineri was evaluated using the micronucleus test and comet assay [11]. V79 cells (Chinese hamster lung fibroblasts) were treated with usnic acid at concentrations of $15,30,60$ and $120 \mu \mathrm{g} / \mathrm{mL}$ and Swiss mice were treated with concentrations of 25, 50, 100 and $200 \mu \mathrm{g} / \mathrm{kg}$. The in vitro results demonstrated damage to the DNA at concentrations of 60 and $120 \mu \mathrm{g} / \mathrm{mL}$ in the comet assay, but none of the concentrations exhibited genotoxic potential against V79 cells on the micronucleus test. Moreover, the researchers found no genotoxic effects at any of the concentrations tested in the in vivo analysis.

Recently, the methanol extract obtained from Cetraria islandica increased the frequency of micronuclei in a dose-dependent manner in lymphocytes from peripheral blood, but the increase was only significant at the highest concentrations tested (50, 100 and $200 \mu \mathrm{g} / \mathrm{mL}$ ) [10]. 


\section{Conclusion}

The present findings demonstrate the in vitro cytotoxic and genotoxic potential of organic extracts and purified barbatic acid obtained from the lichen $C$. salzmannii. The data regarding the in vitro cytotoxic potential of the samples tested corroborate descriptions found in the literature that demonstrate the promising antineoplastic profile of lichen substances against different tumor cell lines, which can lead to the development of drugs for the treatment of cancer. The evaluation of the genotoxicity revealed that the samples tested induced changes in the genetic material of the tumor cells investigated.

\section{References}

1. Ferlay J, Shin HR, Bray F, Forman D, Mathers C, Parkin DM. GLOBOCAN 2008 V2.0, Cancer incidence and mortality worldwide: IARC CancerBase No. 10 [Internet]. Lyon, France: International Agency for Research on Cancer; 2010. Available at: http://globocan.iarc.fr

2. Torre LA, Bray F, Siegel RL, Ferlay J, Lortet-Tieulent J, Jemal A. Global cancer statistics, 2012. CA Cancer J Clin. 2015; 65(2): 87108.

3. DeVita VT, Chu E. A history of cancer chemotherapy. Cancer Res 2008; 8643-8653.

4. Fukuda $Y$, Schuetz JD. $A B C$ transporters and their role in nucleoside and nucleotide drug resistance. Biochem Pharmacol 2012; 1073-1083.

5. Costa- Lotufo LV, Montenegro RC, Alves APNN, Madeira SVF, Pessoa C, Moraes MEA, Moraes MOA. Contribuição dos Produtos Naturais como Fonte de Novos Fármacos Anticâncer: Estudos no Laboratório Nacional de Oncologia Experimental da Universidade Federal do Ceará. Rev Virtual Quim 2010; 2(1): 4758.

6. Boustie J, Tomasi S, Grube M. Bioactive lichen metabolites: alpine habitats as an untapped source. Phytochem Rev 2011; 10: 287-307.

7. Bogo D, Matos MF, Honda NK, Pontes EC, Oguma PM, Santos EC, Carvalho JE, Nomizo A. In vitro antitumour activity of orsellinates. Z Naturforsch 2010; 65: 43-48.

8. Koparal AT, Tüylü BA, Türk $H$. In vitro cytotoxic activities of (+)-usnic acid and (-)-usnic acid on V79, A549, and human lymphocyte cells and their non-genotoxicity on human lymphocytes. Nat Prod Res 2006; 20: 1300-1307.
9. Micheletti AC, Beatriz A, Lima DP, Honda NK, Pessoa CO, Moraes MO, Lotufo FV, Magalhães HIF, Carvalho NCP. Chemical constituents of Parmotrema ichexanthonicum Eliasaro \& Adler isolation, structure modification and evaluation of antibiotic and cytotoxic activities. Quim Nova 2009; 32: 12-20.

10. Grujičić D, Stošić I, Kosanić M, Stanojković T, Ranković B, Milošević-djordjević O. Evaluation of in vitro antioxidant, antimicrobial, genotoxic and anticancer activities of lichen Cetraria islandica. Cytotechnology 2014; 66: 803-813.

11. Leandro LF, Munari CC, Sato VLFL, Alves JM, Oliveira PF, Mastrocola DFP, Martins SPL, Moraes TS, Oliveira Al, Tozatti MG, Cunha WR, Tavares DC. Assessment of the genotoxicity and antigenotoxicity of (+)- usnic acid in V79 cells and Swiss mice by the micronucleus and comet assays. Mutat Res 2013; 753: 101-106.

12. Asahina Y, Shibata S. Chemistry of Lichen Substances. Tokyo: Japan Society for the Promotion of Science; 1954.

13. Culberson CF. Improved conditions and new data for the identification of lichen products by standardized thin layerchromatographic method. J Chromatogr 1972; 72: 1113-1125.

14. Legaz ME, Vicente C. Endogenous inactivators of arginase, arginine decarboxilase and agmnatine amidinohydrolase in Evernia prunastri thallus. Plant Physiol 1983; 71: 300-302.

15. Mosmann T. Rapid colorimetric assay for cellular growth and survival: application to proliferation and cytotoxicity assays. J Immunol Methods 1983; 65: 55-63.

16. Alley MC, Scudiero DA, Monks-hursey ML, Czerwinski MJ, Fine DL, Abbott BJ, Mayo JG, Shoemaker RH, Boyd MR. Feasibility of drug screening with panels of human tumor cell lines using a microculture tetrazolium assay. Cancer Res 1988; 48: 589-601.

17. Rodrigues FA, Bomfim IS, Cavalcanti BC, Pessoa C, Gonçalves RS, Wardell JL, Wardell SM, Souza MV. Mefloquine-oxazolidine derivatives: a new class of anticancer agents. Chem Biol Drug Des 2014; 83: 126-131.

18. Fenech $M$. The in vitro micronucleus technique. Mutat Res 2000; 455: 81-95.

19. OECD. OECD Guidelines for Testing of Chemicals, No. 487: In Vitro Mammalian Cell Micronucleus Test. [Internet] Paris: OECD Publishing; 2014. Available at: http://dx.doi. org/10.1787/9789264224438-en 
20. Speit G, Hartmann A. The comet assay: a sensitive genotoxicity test for the detection of DNA damage and repair. Methods $\mathrm{Mol}$ Biol 2006; 314: 275-286.

21. Collins AR, Oscoz AA, Brunborg G, Gaivão I, Giovannelli L, Kruszewski M, Smith CC, Stetina R. The comet assay: topical issues. Mutagenesis 2008; 23: 143-151.

22. $R$ Development Core Team. R: A Language and environment for statistical computing. [Internet] Vienna: R Foundation for Statistical Computing; 2010. Available at: https://www.r-project. org/

23. Ahti T, Stenroos S, Xavier-filho L. The lichen family Cladoniaceae in Paraiba, Pernambuco and Sergipe, Northeast Brazil. Trop Bryol 1993; 7: 55-70.

24. Boik J. Natural Compounds in Cancer Therapy. Princeton, Minn, USA: Oregon Medical Press; 2001.

25. Martins MCB, Rocha TA, Silva TDS, Cavalcanti-Neto MP, Santos NPS, Silva TG, Aguiar-júnior FCA, Falcão EPS, Pereira EC, Silva $\mathrm{NH}$. In Vitro and in Vivo Antineoplastic Activity of Barbatic Acid. Int Arch Med 2016; 9(63): 1-9.

26. Tavares CA. Lipossomas furtivos contendo ácido barbático de Cladonia salzmannii: desenvolvimento, caracterização e avaliação da atividade antitumoral [MSci Disertation]. Vitória de Santo Antão, Brazil, Portuguese: Universidade Federal de Pernambuco; 2014

Publish in International Archives of Medicine

International Archives of Medicine is an open access journal publishing articles encompassing all aspects of medical science and clinical practice. IAM is considered a megajournal with independent sections on all areas of medicine. IAM is a really international journal with authors and board members from all around the world. The journal is widely indexed and classified Q2 in category Medicine. 